\title{
Evaluation and Modeling of Residual Chlorine in Dangila Town Water Supply System
}

\author{
Wondwesen Tesfaye Semagn ${ }^{1} \quad$ Atikilt Abebe Ketema ${ }^{2} \quad$ Teka Girmay Hishe ${ }^{3 *}$ \\ Eusman Ebrahim Shumey ${ }^{4}$ Mariye Majo Shute ${ }^{5}$ \\ 1.Department of Water Supply and Sanitary Engineering, Water Resource Development Office, Merhabate \\ Wereda, Ethiopia \\ 2.Department of water supply and Sanitary Engineering, Bahir Dar University, Bahir Dar, Ethiopia \\ 3.Hydraulic and Water Resources Department, Faculty of Technology, Debre Tabor University, Debre Tabor, \\ Ethiopia \\ 5.Chemical Engineering Department, Technology Faculity, Debre Tabor University, Debre Tabor, Ethiopia
}

\begin{abstract}
Application of chlorine for protection of drinking water in distribution system is not well established for the Dangila town. The study was conducted to assess chlorine dosing and model for residual chlorine using Water CAD software. The necessary dates were collected using primary and secondary sources. The existing maximum residual chlorine concentration at sample point 6 through the samples by $1.5 \mathrm{~kg} / \mathrm{m}^{3}$ chlorine dose with $3 \mathrm{ml} / \mathrm{s}$ flow rates was found to be $0.17 \mathrm{mg} / \mathrm{l}$. Even, it was less than the minimum recommended WHO and ESA standard $(0.2 \mathrm{mg} / \mathrm{l})$. The amount of total Coliform was found 5 colonies per $100 \mathrm{ml}$ and $\mathrm{pH}(8.68-9.1)$ and the remaining main chemical water quality parameters that analyses were found within WHO \& ESA limits. In order to model the residual chlorine content 3 scenarios were developed. Scenario I and II were developed with $0.6 \mathrm{mg} / \mathrm{l}$ chlorine dose with $26 \mathrm{ml} / \mathrm{s}$ flow rate and $0.5 \mathrm{mg} / \mathrm{l}$ chlorine dose with $22 \mathrm{ml} / \mathrm{s}$ flow rate, respectively. In both scenarios residual chlorine concentration was recorded above the maximum limits $(0.5 \mathrm{mg} / \mathrm{l})$ around the injection point which is a bit higher than the maximum limit, while 4 sample points got less than $0.2 \mathrm{mg} / \mathrm{l}$. Scenario II, all residual chlorine results were below $0.5 \mathrm{mg} / \mathrm{l}$, but still the farthest 4 sample points got lower than $0.2 \mathrm{mg} / \mathrm{l}$. To solve the above problem Scenario III was developed with three injection points at reservoir, Junction 4 \& $55^{\prime \prime}$ within $0.45,0.15$ and $0.2 \mathrm{mg} / \mathrm{l}$ chlorine dose to keep the residual chlorine concentration acceptable. Therefore, installing two additional chlorine injection points were the best solution that identified from the analysis.
\end{abstract}

Keywords: Residual chlorine, Water quality and Water CAD

DOI: $10.7176 / C E R / 12-1-01$

Publication date: January $31^{\text {st }} 2020$

\section{INTRODUCTION}

A human can survive for weeks without food, but it only a few days without water. According to Clark, 2012 water should be free from chemical and biological contaminants(Males, Grayman et al. 1988). In each year, millions of people, particularly children, die from diarrhea caused by contaminated drinking water. Water related diseases include waterborne infections such as cholera, typhoid, infective hepatitis and schistosomiasis. Disinfection is an important step to ensure that water is safe to drink. In water supply system, adding disinfectants to destroy microorganisms that can cause disease in humans is common. Even though there are several methods of disinfection in the world, developing countries like Ethiopia use chlorine to disinfect the water they use. According to chlorine is the most widely used disinfectant for the inactivation of waterborne pathogens in drinking water supplies and historically has questionably made the greatest contribution to the public health protection of consumers (Bolton and Cotton 2011);(Yee, Abdullah et al. 2006);(Post, Atherholt et al. 2011, Soyupak, Kilic et al. 2011). Chlorination is a relatively simple and cost effective process which does not require extensive technical expertise and which is capable of dealing with supply systems of varying size by altering dosing systems or storage for chemical contact.

Wei et al. (2010) suggested that, chlorination is dramatically reducing the occurrence of waterborne diseases such as typhoid, cholera, and hepatitis, as well as gastrointestinal illness(Wei, Ye et al. 2010). However, chlorine can also react with natural materials in the raw water to form disinfection by-products (DBPs) that are hazardous to health in long-term exposure to disinfection by-products and increased risk of cancer and potential adverse reproductive effects.

In Dangila, town water supply disinfection of chlorine is mix manually in service reservoir with unskilled person. When, dissolved chlorine travels through the distribution system, it reacts with natural organic matter (NOM) in the bulk water, with Biofilms and tubercles on the pipe walls, or with the pipe wall material itself. This reaction results in a decrease the chlorine residual and a corresponding increase in disinfection by-products(Males, Grayman et al. 1988).

The residual chlorine in water distribution can be affected by different factors like Temperature, $\mathrm{pH}$ and turbidity. Temperature is one of the important parameter of water and it is important for its effects on the chemistry 
and biological reactions on the organisms in the water will lead to the reduction in the amount of residual chlorine that can enhanced growth of microorganism.

When the amount of $\mathrm{pH}$ in the distribution system is less than 7 , it create corrosion in distribution system that can cause more chorine bi products and the chlorine is less effective if the pH of water exceeds 8.0 (Ustad 2018). The other factor is high levels of turbidity that can protect microorganisms from the effects of disinfection, giving rise to a significant chlorine demand and reducing the performance of disinfection efficiency(Sorlini, Palazzini et al. 2013). On the other hand the value of $\mathrm{pH}$ affects treatment processes, coagulation and disinfection with chlorine based chemicals(Hu, Aryal et al. 2010). According to Myer and Shaw, 2006 and Bolton and Cotton, 2011, water to be chlorinated it should have a turbidity values $\leq 5$ NTU(Myre and Shaw 2006, Bolton and Cotton 2011). Chlorination is even more effective when less than 1 NTU. The other very important chemical water quality parameters that can affect chlorine demand are Calcium, Magnesium, Chlorides, Nitrates and Nitrites (Temgoua 2011).

To solve the problems related to water born dieses it is very important to study the amount of residual chlorine in water distribution system. Water cad is one of very important soft ware's that is used to model Pressure, velocity, head loss, water age (Kabir, Tesfamariam et al. 2015) and residual chlorine (Goyal and Patel 2015) in the water distribution system (Mekonnen 2015).

\section{MATERIALS AND METHODS}

\subsection{Description of study area}

Location of Dangila is in Awi Zone Amhara Regional State. This town has latitude and longitude Coordinates: $11^{\circ} 16^{\prime} \mathrm{N} 36^{\circ} 50^{\prime} \mathrm{E}$ with an average elevation of 2125 meters above sea level. It is far from Addis Ababa, about 485kilo meters, and from Bahir Dar $78 \mathrm{~km}$ towards road of Addis Abeba. The central statistical agency in 2005E.C, the town has an estimated total population 26,704and 34,629 in 2017.Application of chlorine for protection of drinking water in distribution system is not well established for the Dangila town water supply system. As most of Ethiopian towns, Dangila town has unbalance chlorine adding and can affects human in chronic cause and sometime actuating effects. The source of water supply system of Dangila town is from four wells from those the three are functional and the other one is not functional. The system of chlorine application is manually on reservoirs that can result in fluctuations on chlorine dosage.

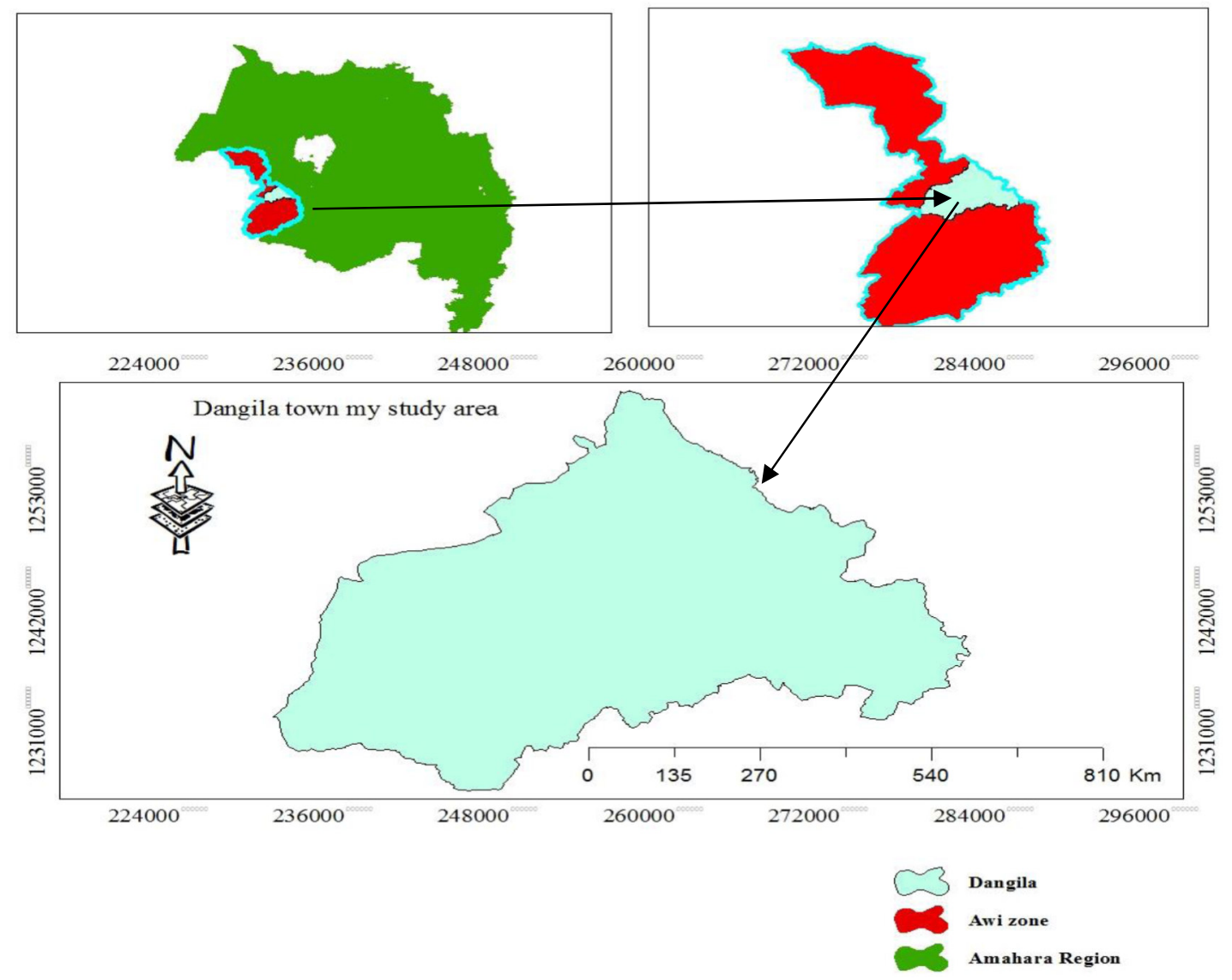

Figure 1Topographical location of the study area 


\subsection{Sampling Sites}

Selecting water quality sample points was one of the most important steps for designing and exploiting of water quality monitoring in the network. Water quality is usually specified by physical, chemical and biological parameters. These are corrected and determining their relations is complicated. However, these are necessary for specified of water sample points but measuring all of them is not economical, so samplings selected depend on the Ethiopia water quality standard agency,2013.According to ESA, 2013 Sampling for bacteriological examination and other water quality parameters should be regular and its frequency and sizes would mainly depend on different type of factors(Ododo). These are quality of the water harnessed, type of treatment for drinking worthiness, risks of contamination, background of public water supply network and number of people served.

The minimum sample size for drinking water in the distribution Population served Sample was taken based on the population. Based on Ethiopia Water Quality Standards Agency, 2013 for the population which is Less than 5,000, one sample, for 5,000-100,000 one sample per 5,000 populations and Above 100,000 one sample per 10,000 populations plus 10 sample additional(Ododo).

\subsection{Sampling and Laboratory analysis}

After fixing the number of sampling sites, the next step was collecting water samples to examined different physico-chemical and biological parameters that have adverse impact on chlorine demand. Based on this in addition to secondary date's, primary data's were collected from the selected eight sampling points labeling as SP1,SP2,SP3,SP4,SP5,SP6,SP7 and SP8.The parameters selected to examined the effect of the water quality parameters on residual chlorine concentration were Temprature, $\mathrm{PH}$,turbidity and total coli forms. The evaluation and modeling of the amount of residual chlorine in the distribution system was carried out by the help of water cad software.

\section{RESULTS AND DISCUSSION}

\subsection{Water Quality Related Data and Their Effect on Chlorine Demand}

Except $\mathrm{pH}$ (8.68-9.1), the main chemical water quality parameters that analyses such as $\mathrm{CaCO}_{3}, \mathrm{Mg}, \mathrm{F}, \mathrm{NO}_{3}, \mathrm{NO}_{2}$, $\mathrm{Mn}, \mathrm{Fe}$ and Chloride were found within WHO \& ESA limits which does not have not significant adverse impact on chlorine residual.

\subsection{Assessment of Existing Microbial and Residual Chlorine}

Dangila`s town water quality analysis as the Water, Energy and Irrigation Guideline office 2009 E.C reported that, the town WSDS have shown not detected with coliforms. But, on this study those report was not exact. Bacteriological to be safe in drinking water supply system, fecal and total coliforms must be null at any $100 \mathrm{ml}$ drinking water samples. During the study period it was found, disinfection with $1.5 \mathrm{~kg}$ chlorine dose solution by $3 \mathrm{ml} / \mathrm{s}$ flow rates were not full disinfect all the distribution systems. The existing maximum residual chlorine concentration at sample point six through the distribution system by $1.5 \mathrm{~kg} / \mathrm{m}^{3}$ chlorine dose with $3 \mathrm{ml} / \mathrm{s}$ flow rates was found to be $0.17 \mathrm{mg} / \mathrm{l}$ as shown on figure 2 which was less than the minimum recommended by WHO and ESA standard $(0.2 \mathrm{mg} / \mathrm{l})$

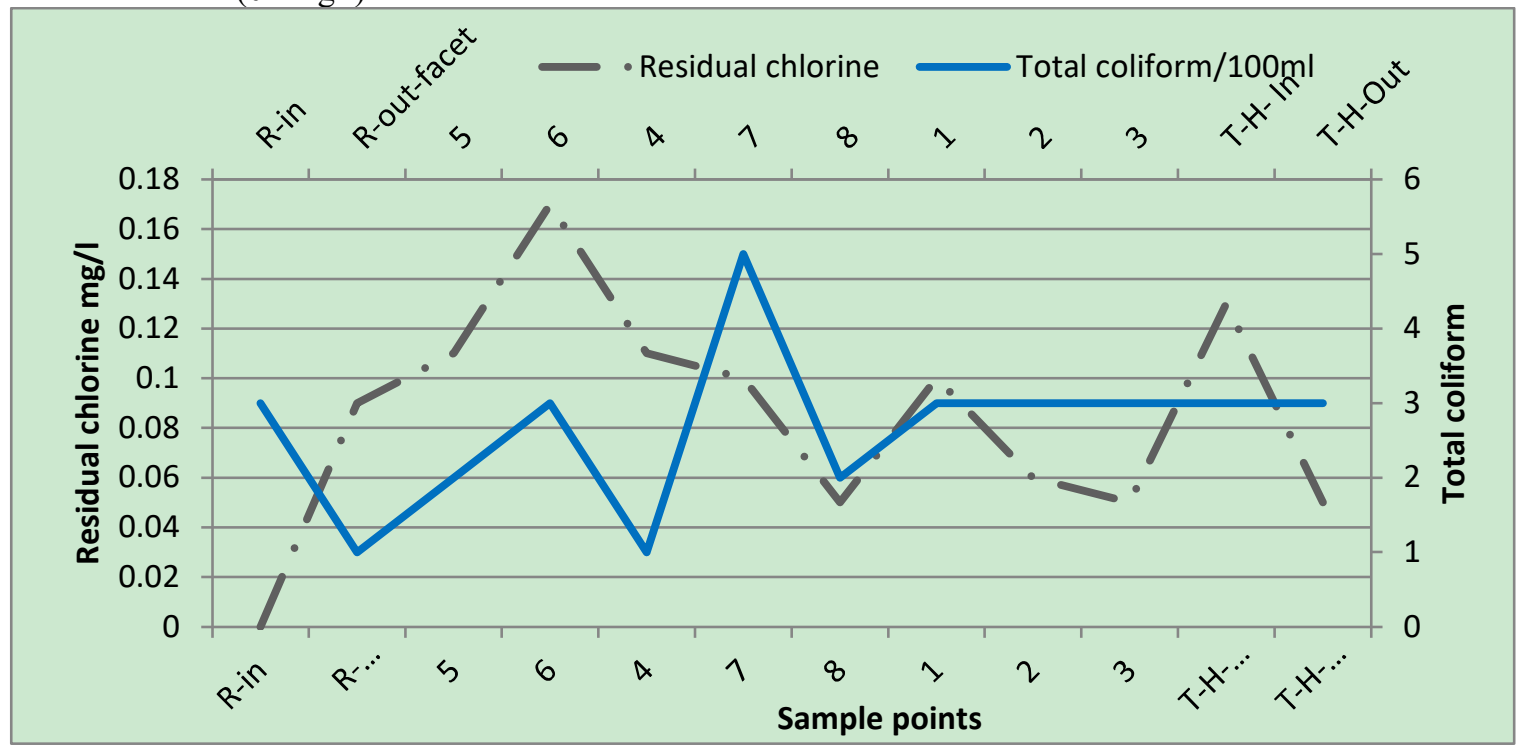

Figure 2 Current town residual chlorine versus total coliforms

From the total residual chlorine analysis samples that taken at consumer taps, $50 \%$ of result has recorded above $0.1 \mathrm{mg} / \mathrm{l}$ (including it) but, less than $0.2 \mathrm{mg} / \mathrm{l}$ and the other $50 \%$ have resulted below $0.09 \mathrm{mg} / \mathrm{l}$. 
The residual chlorine was analyzed after 30 minute chlorine demands (Yee, Abdullah et al. 2006). A chlorine dose solution form in mixing tank with the amount of $1.5 \mathrm{~kg}$ was calculated as follow:-

From the $1.5 \mathrm{~kg}(\mathrm{Ca}(\mathrm{OCl}) 2$, net chlorine was calculated as 1500 gram*65\%; Dose concentration $=\frac{1500 * 65 \%}{1000 \mathrm{l}}=975 \mathrm{mg} / \mathrm{l}$

Equation 1

Initial chlorine dose drops from separated chlorine mixing tank with $2 \mathrm{ml} / \mathrm{s}, 5 \mathrm{ml} / \mathrm{s} \& 7 \mathrm{ml} / \mathrm{s}$ chlorine solution rates in to the well discharge proportion amounts. $2 \mathrm{ml} / \mathrm{s}$ : chlorine dose flow rates, $975 \mathrm{mg} / 1$ : chlorine dose in mixing tank

For this study, the value of initial chlorine concentration when, the three wells out of four were worked at the same time $(561 / \mathrm{s})$ with $7 \mathrm{ml} / \mathrm{s}$ dose flow rates. The calculated initial chlorine concentration value was $0.12 \mathrm{mg} / \mathrm{l}$. This initial chlorine concentration was not enough to get the minimum residual chlorine throughout distribution system. Although, for other wells operates in different time by $7 \mathrm{ml} / \mathrm{s}$ chlorine dose flow rates the amount of initial chlorine concentration proportion with well discharge the residual chlorine recorded within the recommended ranges $(0.2-0.5 \mathrm{mg} / 1)$.

\subsection{Assessment of Disinfection Process with $1.5 \mathrm{~kg}$ Chlorine}

The existing of free residual chlorine values were examined in distribution systems as pervious explained all results were recorded less than the minimum recommended values $(0.2) \mathrm{mg} / \mathrm{l}$. To meet the minimum residual chlorine were throughout the distribution system adjusts the chlorine solution flow rates with different amounts of chlorine dose. So, using $1.5 \mathrm{~kg}(\mathrm{Ca}(\mathrm{OCl}) 2$ dose solution $(975 \mathrm{mg} / \mathrm{l})$ within adjusted solution the flow rate in to $2 \mathrm{ml} / \mathrm{s} ; 5 \mathrm{ml} / \mathrm{s} \&$ $7 \mathrm{ml} / \mathrm{s}$ were assessing residual chlorine at figure 3 .

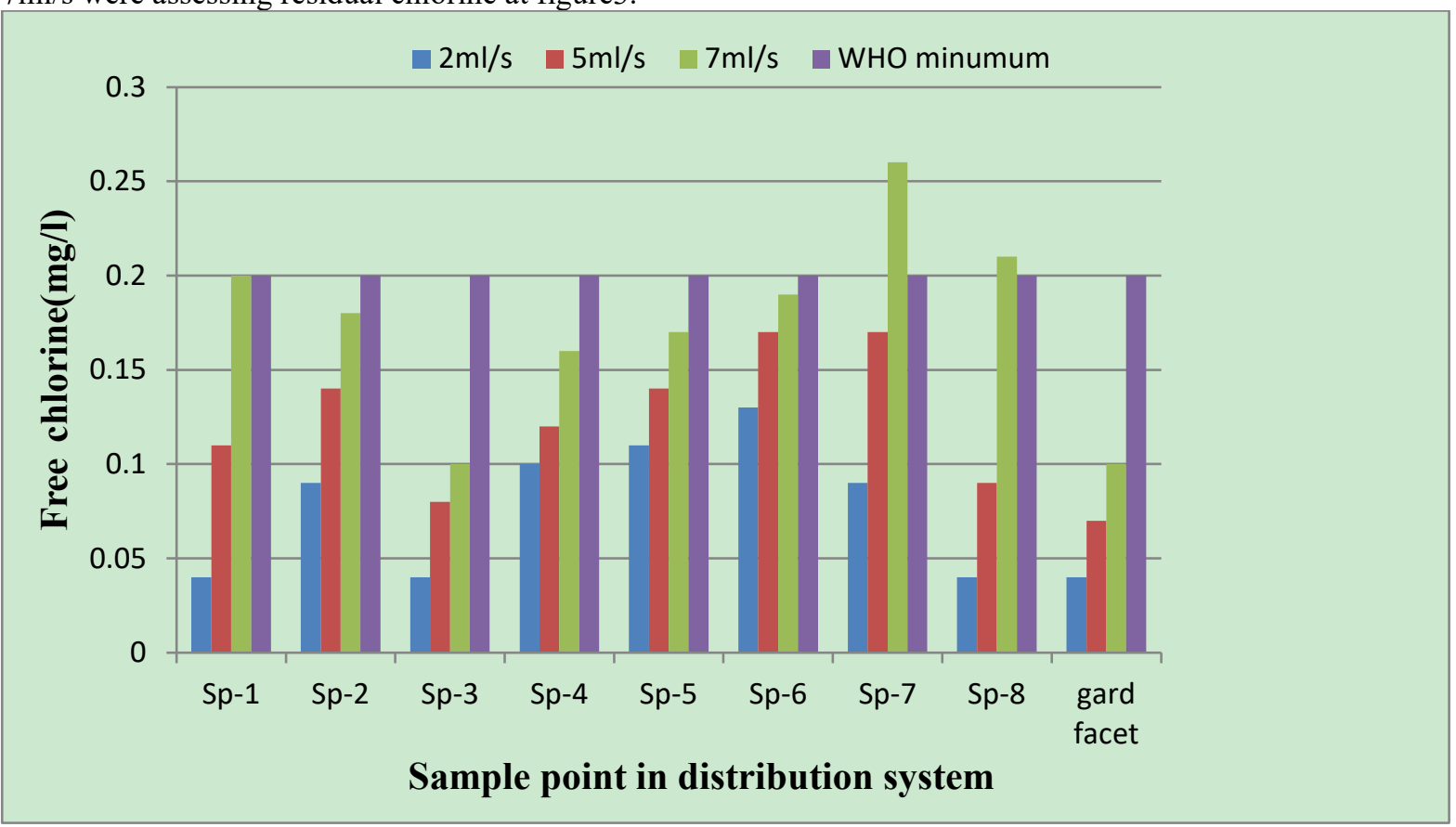

Figure 3 Residual chlorine value with $1.5 \mathrm{~kg}$

From those sample points analysis residual chlorine results in the distribution system by adjusting flow rates in to $2 \mathrm{ml} / \mathrm{s}, 5 \mathrm{ml} / \mathrm{s}$ and $7 \mathrm{ml} / \mathrm{s}$ the recorded values were; for $2 \mathrm{ml} / \mathrm{s}$ chlorine flow rates the residual chlorine was recorded $37.5 \%$ between the range of $0.1-0.2 \mathrm{mg} / 1$ and $62.5 \%$ was less than $0.1 \mathrm{mg} / 1$. For $5 \mathrm{ml} / \mathrm{s}$ chlorine flow rates the residual chlorine was recorded $75 \%$ which was between the range of $0.1-0.2 \mathrm{mg} / \mathrm{l}$ and $25 \%$ was less than $0.1 \mathrm{mg} / 1$ and also, for $7 \mathrm{ml} / \mathrm{s}$ chlorine flow rates the residual chlorine was recorded $37.5 \%$ between the range of 0.2 $-0.3 \mathrm{mg} / \mathrm{l}$ and $62.5 \%$ was between the range of $0.1-0.2 \mathrm{mg} / \mathrm{l}$. The entire three alternative except $(7 \mathrm{ml} / \mathrm{s} ; 37.5 \%)$ the other alternatives cannot found the minimum residual chlorine $(0.2 \mathrm{mg} / \mathrm{l})$ in far dead end of town networks. Even, in the center of the town have not found the minimum required residual chlorine.

\subsection{Assessment of Disinfection Process with $2 \mathrm{~kg}$ Chorine}

Chlorine solution concentration form in mixing tank with the amount of $2 \mathrm{~kg} \mathrm{Ca}(\mathrm{OCl})_{2}$ was calculated as follow:Dose concentration $=\frac{2000 * 65 \%}{1000 l}=\frac{1300 \mathrm{mg}}{l}$

Equation 2 


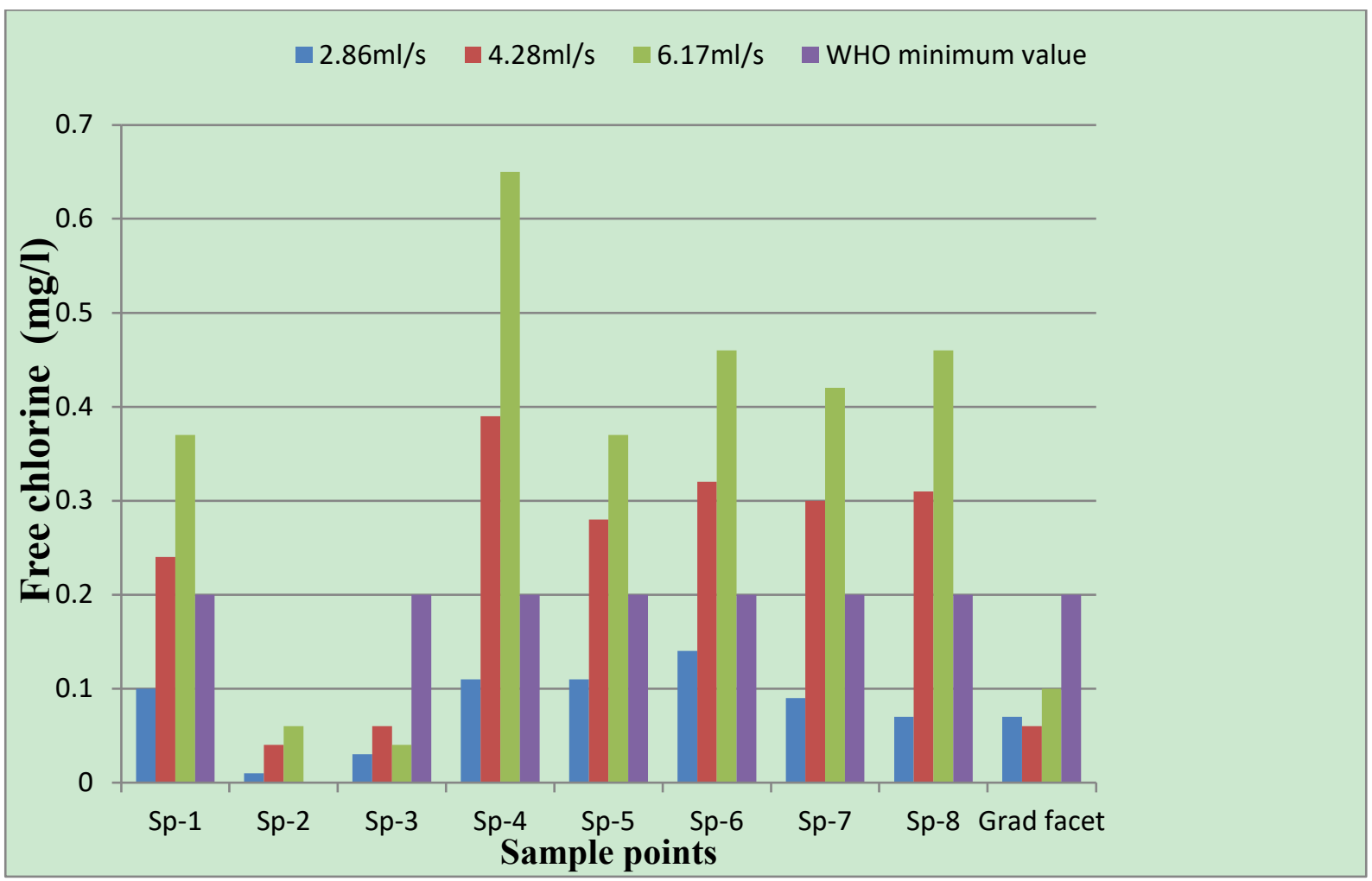

Figure 4 Residual chlorine with $2 \mathrm{~kg}$ chlorine solution

The residual chlorine content in the distribution systems when applied $2 \mathrm{~kg} \mathrm{Ca}(\mathrm{OCl})_{2}$ chlorine dose solution with different flow rates of $2.86 \mathrm{ml} / \mathrm{s}$ in all samples were found below $0.14 \mathrm{mg} / \mathrm{l}$. However, within this amount of dose solution using $4.28 \mathrm{ml} / \mathrm{s}$ average flow rates residual chlorine were occurs $25 \%$ less than $0.07 \mathrm{mg} / \mathrm{l}$ and the rest $75 \%$ were found between $0.2-0.5 \mathrm{mg} / \mathrm{l}$. Adjusting injection amount of chlorine solution with average value of 6.17 $\mathrm{ml} / \mathrm{s}$ residual chlorine results have recorded $62.5 \%$ found between $0.2-0.5 \mathrm{mg} / \mathrm{l}$ and one sample was recorded 0.65 $\mathrm{mg} / \mathrm{l}$, this value was above the maximum limits and also, $25 \%$ below $0.1 \mathrm{mg} / 1$. When $2 \mathrm{~kg} \mathrm{Ca}(\mathrm{OCl})_{2}$ chlorine does concentration flow rate amount increases do not address all the distribution system with recommended ranges of residual chlorine, rather maximum residual chlorine has been found $(0.65 \mathrm{mg} / \mathrm{l})$.

\subsection{Model Run and Calibration}

The objective of calibration of water quality model is to minimize the difference between the field observed and model simulated values for chlorine concentration. For calibrations that was selected the most appropriated fitted of the trial results which have overlay above correlation line within the value of observed and simulated results. So that, from trial option it was assessed with $2 \mathrm{~kg}$ chlorine dose by $4.28 \& 6.17 \mathrm{ml} / \mathrm{s}$ chlorine solution flow rates observed residual chlorine result had recorded within the recommended values when compared to other option and it used for model calibration as observed data.
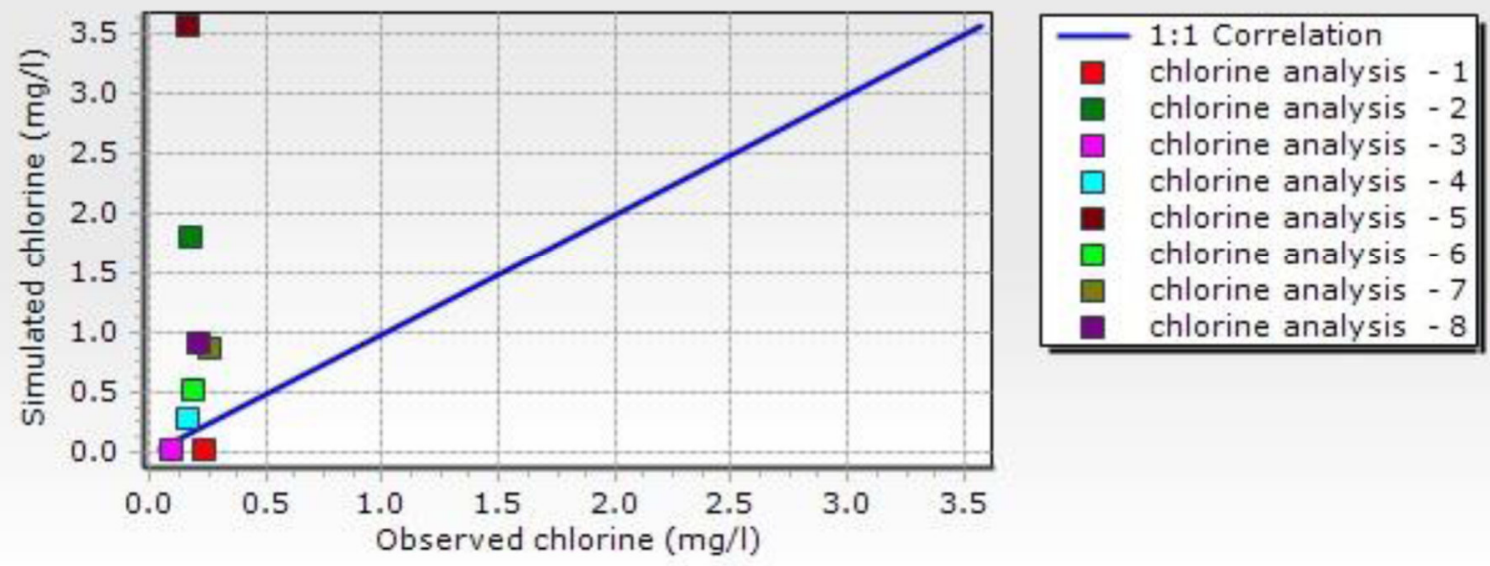

Figure 5 observed vs simulated chlorine values 
The model calibrate with recommended scenarios for selected initial injection value $0.45 \mathrm{mg} / 1$ and two additional injection points with base chlorine dose $0.15 \mathrm{mg} / \mathrm{l}$ and $0.2 \mathrm{mg} / \mathrm{l}$. Because, within short periods in all networks have got residual chlorine concentration within standard limits $(0.2-0.5 \mathrm{mg} / \mathrm{l})$.

\subsubsection{Model Scenario One: Initial Chlorine Dose 0.6mg/l}

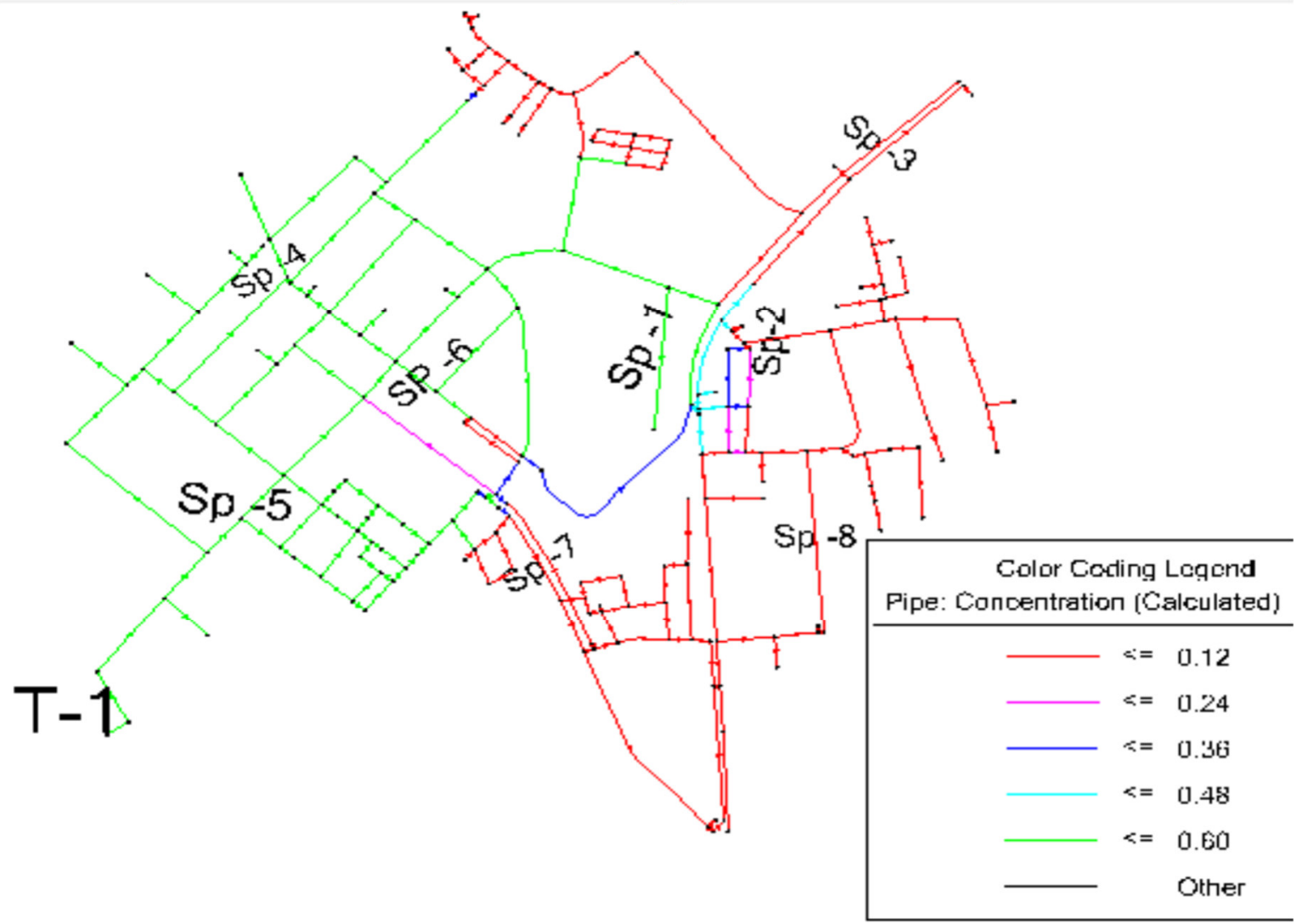

Figure 6 Residual chlorine with $0.6 \mathrm{mg} / \mathrm{l}$ at after 18 hour

As shown on figure 6 the Chorine concentration amount in the most pipes nearest to the reservoir was found $0.6 \mathrm{mg} / \mathrm{l}$ and it was above the maximum limits $(0.5 \mathrm{mg} / \mathrm{l})$. The other pipes in the network were found $0.12 \mathrm{mg} / 1$ which was below the minimum limits $(0.2 \mathrm{mg} / \mathrm{l})$. To manage this scenario required.

\subsubsection{Model scenario two: Initial Chlorine Dose $0.5 \mathrm{mg} / \mathrm{l}$}

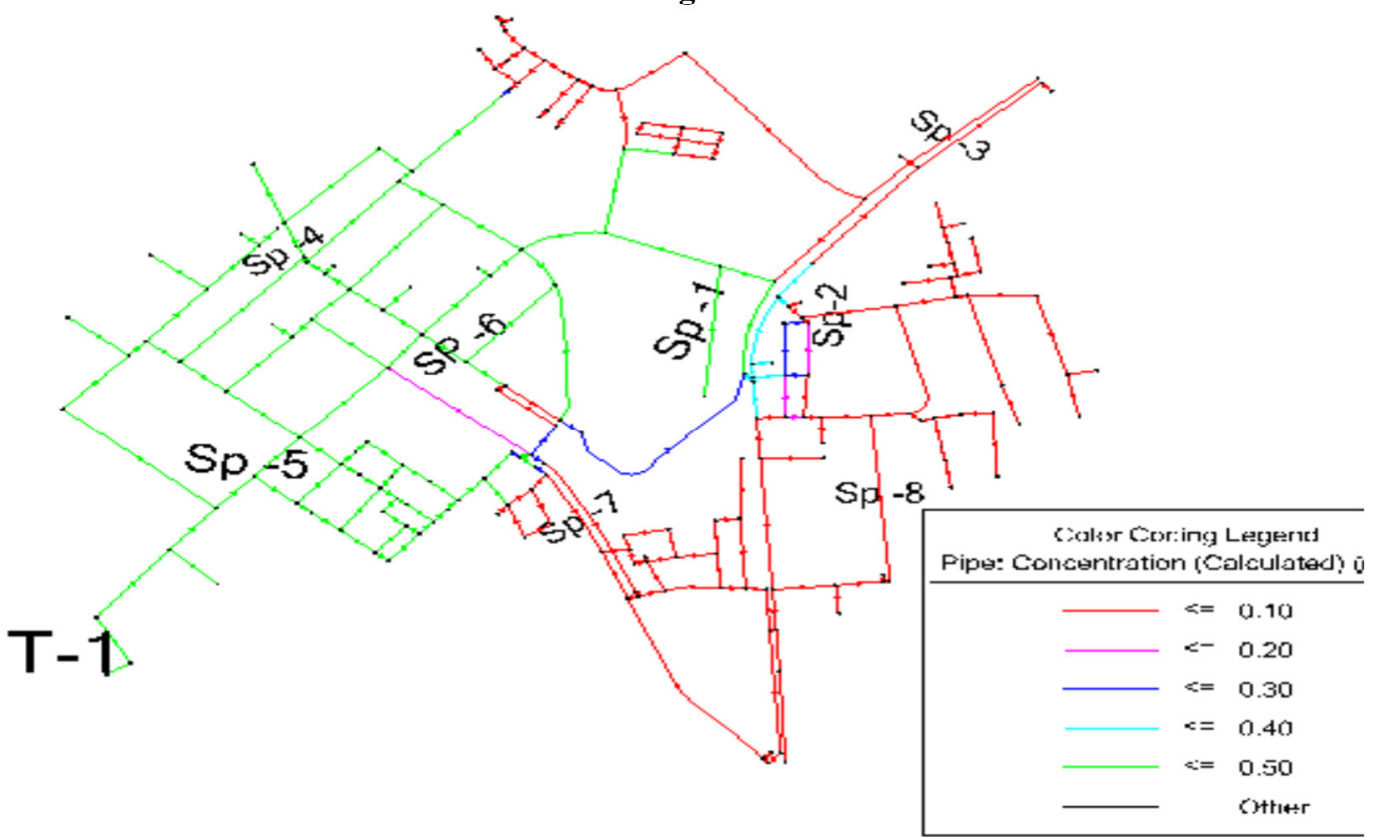

Figure 7 Residual chlorine with $0.5 \mathrm{mg} / 1$ after 18 hour 
In scenarios two use initial chlorine concentration of $0.5 \mathrm{mg} / \mathrm{l}$, the values of free chlorine more than $50 \%$ results founds within the range of $0.4-0.5 \mathrm{mg} / \mathrm{l}$. While, the rest pipe networks have less than $50 \%$ that displayed between $0-0.1 \mathrm{mg} / \mathrm{l}$ of free chlorine. In this scenario, the values of free chlorine model fluctuated between 0.08 $0.5 \mathrm{mg} / \mathrm{l}$ at each sampling points. In this simulation of the existing situation indicated that the distribution of residual chlorine in the network is not adequate in most of the areas. Second scenario also could not solve the problem. In case of such reason, applying injection points to the distribution networks to get adequate the minimum residual chlorine throughout the system.

\subsection{Assessment of Injection Points}

Injection points use to confirm area where cannot get minimum level of chlorine in the networks. To balance residual chlorine throughout the distribution system initial concentration of $0.45 \mathrm{mg} / \mathrm{l}$ and additional two chlorine injection points within 0.15 and $0.2 \mathrm{mg} / 1$ was applied. Injection base chlorine concentrations were installing near SP-7 at J-4 and SP-1at junction 55' respectively. Sample point seven selection criteria, during assessing existing situation were due to the existence of high total coliform.

Water CAD was used to evaluate free chlorine and to predict areas where, the residual chlorine concentration was lower than the minimum recommended value of $0.2 \mathrm{mg} / \mathrm{l}$ in distribution network. As can show figure 3-6, for each chlorine concentration, the final chlorine injection rates by the proposed model were lower than those obtained from field assessments. When the water quality responses of previous two scenarios are compared, it can be seen that both proposed models not found the minimum chlorine residuals of $0.20 \mathrm{mg} / \mathrm{l}$ for all the networks. On the other hand, maximum chlorine residual values obtained by the proposed model were greater than the one obtained nearest to service reservoir. But, these differences are not significant and the maximum chlorine residuals were still in the range of permissible residual limits. It was clearly seen that average residual values were in the range of $0.20-0.55 \mathrm{mg} / \mathrm{l}$ for all the networks, more uniform residual distributions are obtained especially, near injection points and surrounding areas.

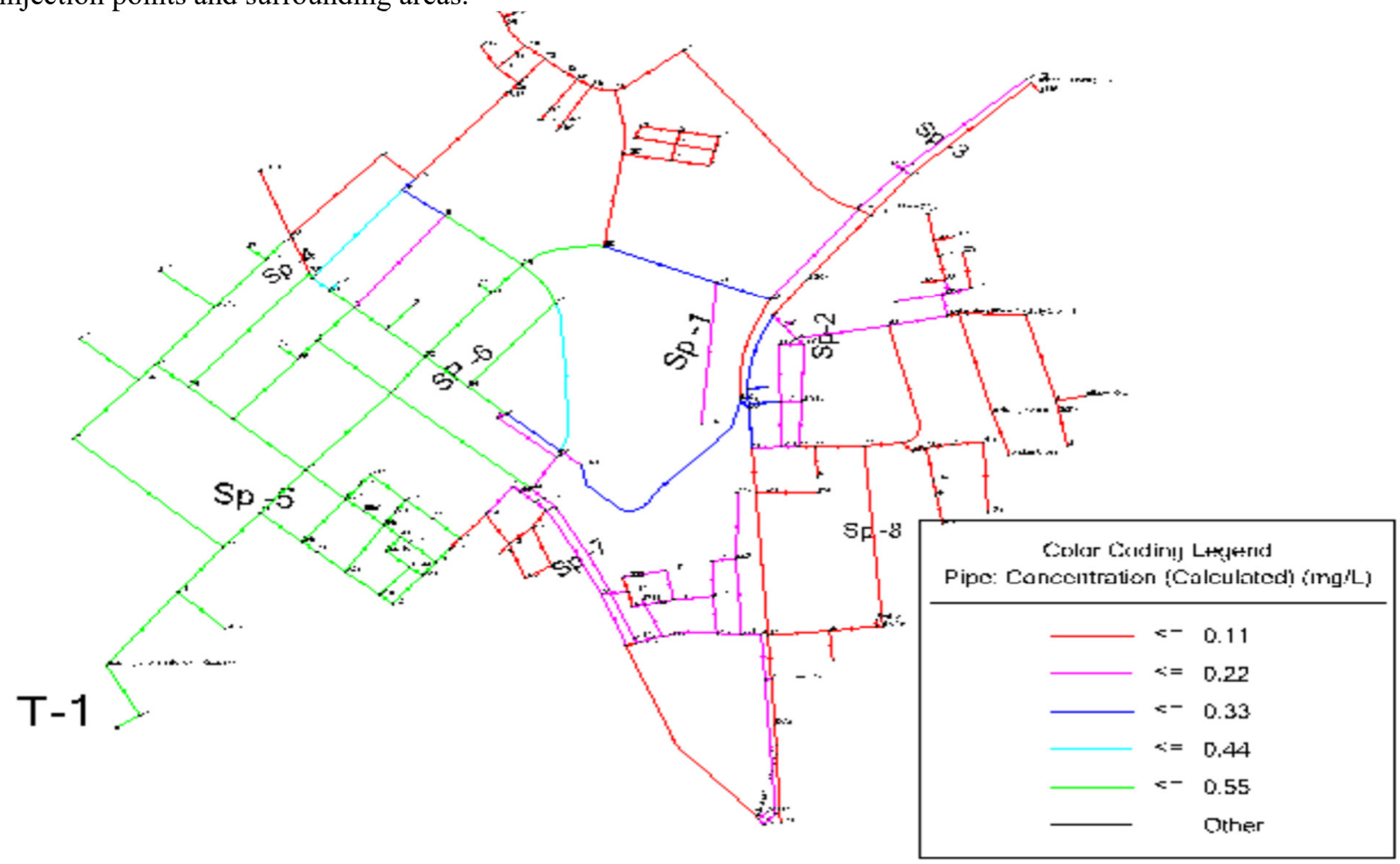

Figure 8Residual chlorine at 12 hour $(0.45+0.15+0.2) \mathrm{mg} / \mathrm{l}$

When the model was run, initial mean residual chlorine surrounding service reservoir has recorded $0.45 \mathrm{mg} / \mathrm{l}$. With this value most of the nodes and pipes in 12 hours' duration the result have displayed within the recommended values in including farthest to service reservoir as shown on figure 8 . When compare to the previous all model scenarios within short time (12 hours) the values of this scenario was the best adequate but, some existing end points have not got the minimum values of residual chlorine. To fit the most and appropriate chlorine dose in all the networks were using another option at 20 hour duration as shown figure 8 . 


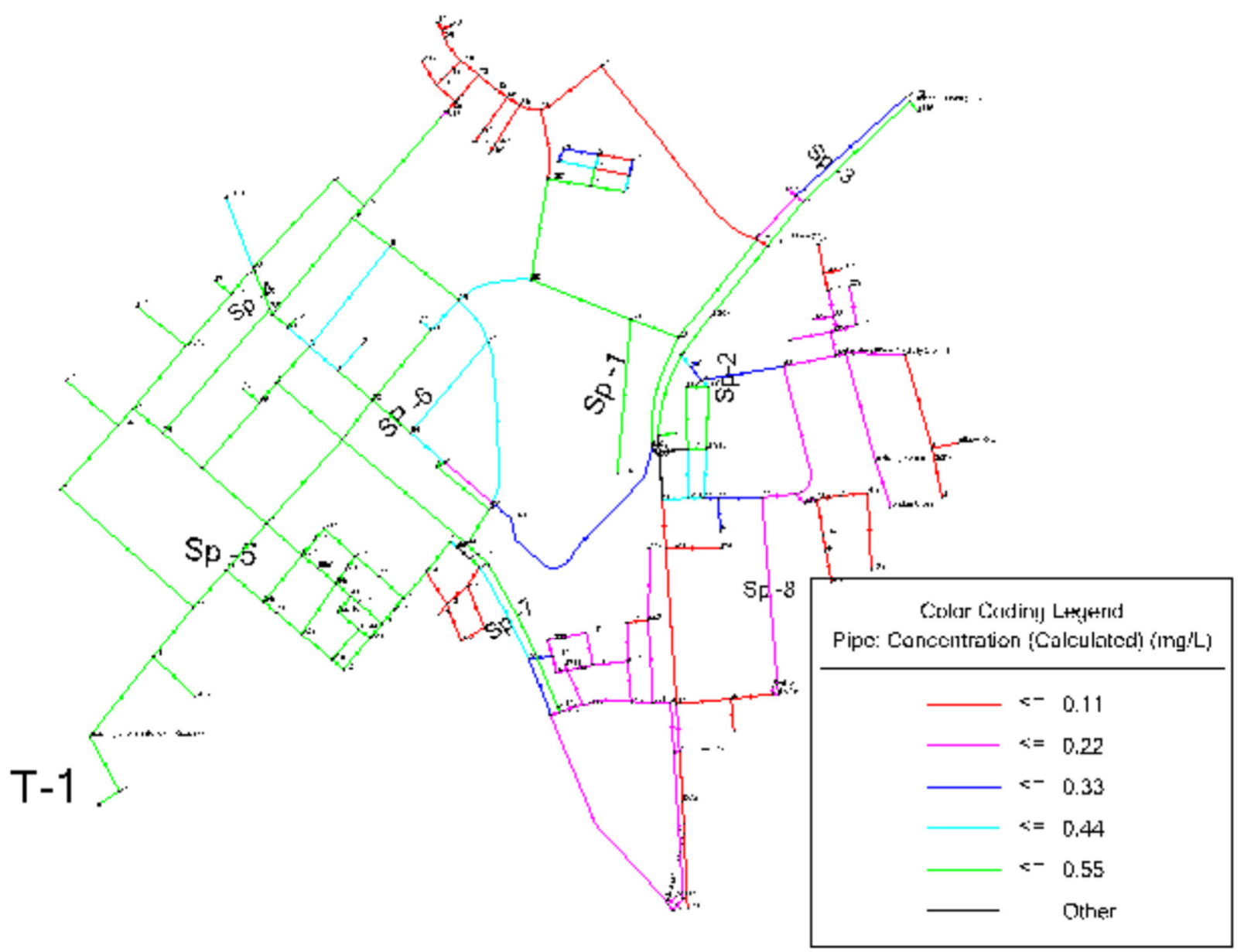

Figure 9 Residual chlorine at 20 hour $(0.45+0.15+0.2) \mathrm{mg} / \mathrm{l}$

In the third scenario, the values of free chlorine in most of the samples were found within the WHO \& ESA guideline $0.2-0.5 \mathrm{mg} / \mathrm{l}$. In this model scenario, the town water distribution networks have more than $90 \%$ part of the pipes and nodes have residual chlorine value within the range of $0.15-0.5 \mathrm{mg} / \mathrm{l}$ in all distribution networks while, regarding sample points were founds between $0.2-0.5 \mathrm{mg} / \mathrm{l}$. So that, additional two chlorine injection points with initial concentration at service reservoir $0.45 \mathrm{mg} / \mathrm{l}$ and using $0.15 \& 0.2 \mathrm{mg} / 1 \mathrm{dose}$ injection points respecting location it address all networks with recommended values at short time. Generally, additional chlorine injection points are very essential for supply adequate all the networks because; reservoir chlorination was not overlay all the networks with short time and also not got the minimum recommended result at the dead end of the pipes.

\subsection{Disinfection Model Scenarios Evaluation}

Table 3-1 shows, the values of residual chlorine monitoring data on the water network through the day, which started from 12 hours to 18 hours for the three scenarios. 


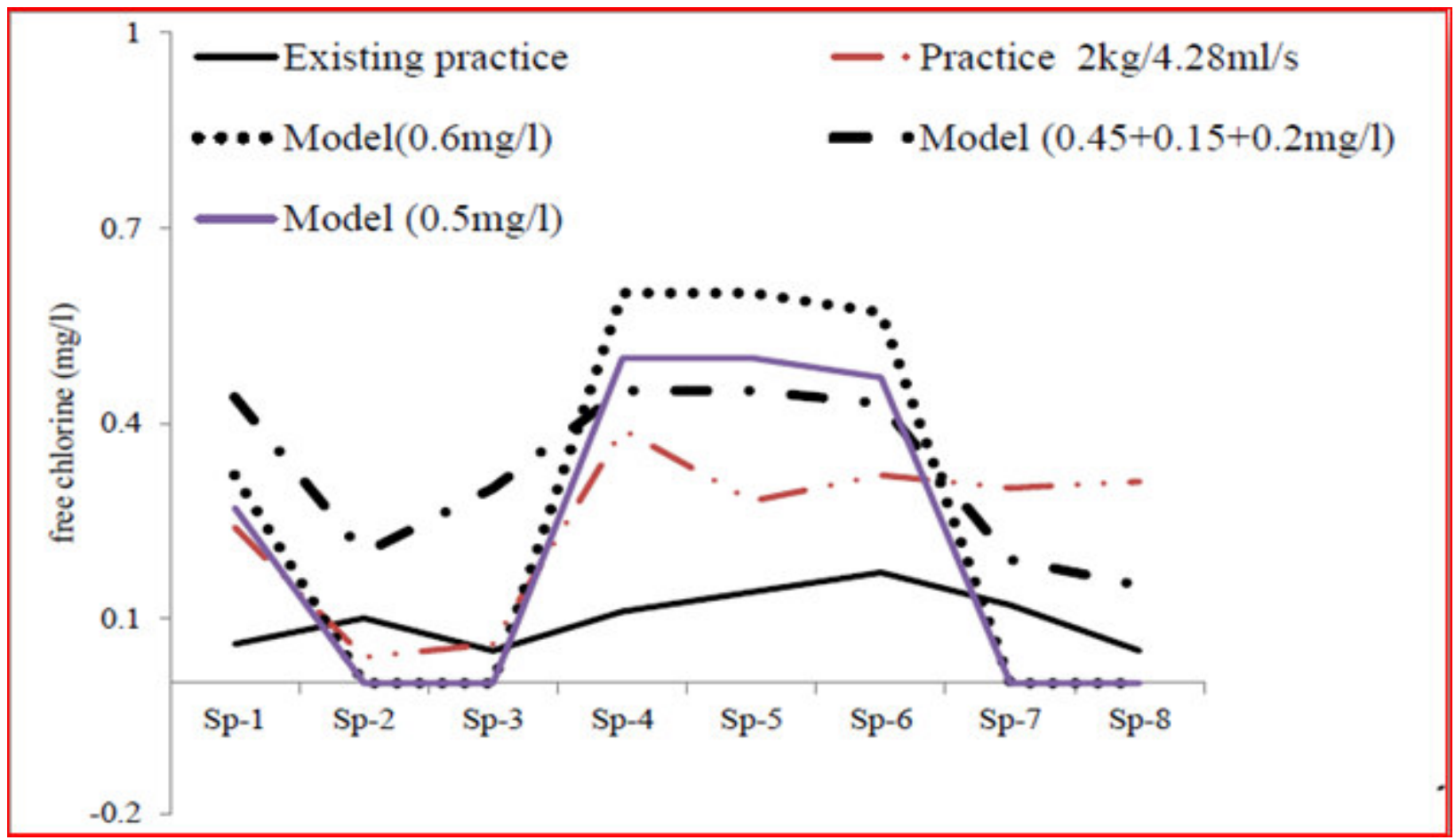

Figure 10 Free chlorine value relations at 12 hours

When compared each scenarios in 12 hours third one was most appropriated and the results has displayed within short period $75 \%$ of networks have residual chlorine within the range of $0.2-0.45 \mathrm{mg} / \mathrm{l}$. This scenario results has display within range of WHO standards. So that, the third model scenario was the best economical methods and recommended for the office.

\subsection{Model Validations}

For validations we selected the most appropriated fitted of the trial results have recorded and this overlay within short time. These trial selected depends on the result have which related to the standard limits. So that, from trial practice we assessed with $1.5 \mathrm{~kg} \& 2 \mathrm{~kg}$ solution by $7 \mathrm{ml} / \mathrm{s} \& 4.28 \mathrm{ml} / \mathrm{s}$ dose flow rates result have recorded within the range of 0.1-0.5 mg/l values when compared to other results trial practice and it used for model calibration as observed data. The model calibrate with recommended scenarios selected $(0.45+0.15+0.2 \mathrm{mg} / \mathrm{l})$ because, within short periods in all networks have got residual chlorine concentration within standard limits.

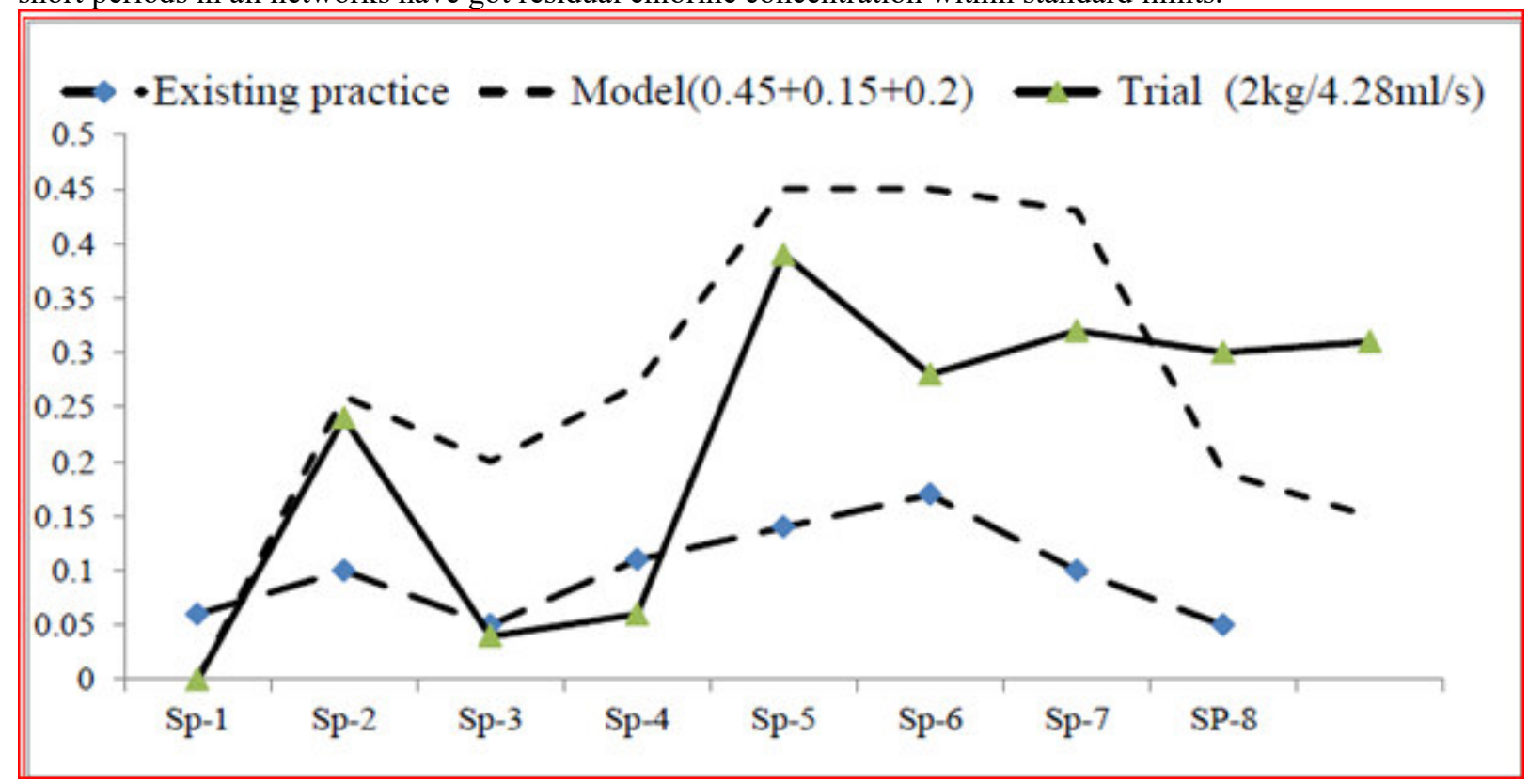

Figure 11 mean residual chlorine validation at sampling points

As seen in table (4.10) and express with figure (4.19) for option one, existing practice and chlorine dose 
solution $2 \mathrm{~kg} / \mathrm{l}$ by $4.28 \mathrm{ml} / \mathrm{s}$ dose flow rates there were statistical significant differences $(\mathrm{p}=0.006, \mathrm{P}$-value $<0.05$ ). The second option, existing practice and scenario model $(0.45+0.15+0.2 \mathrm{mg} / \mathrm{l})$ also there were statistical significant differences $(\mathrm{p}=0.002, \mathrm{P}-\mathrm{value}<0.05)$ between the existing practice and on this new scenarios model free chlorine value within 18 hours, at all sample points the mean value was within $0.15-0.5 \mathrm{mg} / \mathrm{l}$. Even, at this scenario for sample points $(3 \& 8)$ respectively which were far from service reservoir have dead end, low pressure, low velocity and high water age which have the means value was between $0.15-0.5 \mathrm{mg} / \mathrm{l}$. So that, the second option calibration validation was which indicate the best fit scenario for free chlorine value in the networks compared to other options. it is clearly put the amount of free chlorine measured sample points in the third scenario was the highest value when compared with the other the scenarios and should be considered to get safe water from microbial contamination.

\section{Data Availability Statement}

Some of the data, models, or code generated or used during the study are available from the corresponding author by request, for collaborative purposes, including the following: Residual chlorine and the water cad used to make residual chlorine profile calculations.

\section{Acknowledgments}

We would like to thank Atikilt Abebe (Ph.D.) and Co- Advisor Yesuf Ali (MSc.) for the guidance, encouragement and supported. We would also like to express our appreciation to the staff of water supply and sanitary engineering department Bahir Dar university, Dangila Water and Sewerage office and Dangila woreda water development office, Debre Tabor University that helped us to get all the necessary data and financial support. Finally we would like to thank to the developer of water cad for analysis of residual chlorine.

\section{CONCLUSIONS}

Dangila's town residual chlorine concentration in the entire distribution networks under existing conditions has below $0.17 \mathrm{mg} / \mathrm{l}$. Chlorination level current practice $100 \%$ of collected samples does not comply with WHO and ESA minimum limit $(0.2 \mathrm{mg} / \mathrm{l})$. The bacteriological assessment confirmed that no fecal coliforms exist rather total coliform has happened with the maximum number of 5 colonies per $100 \mathrm{ml}$ sample. By using $1.5 \mathrm{~kg}$ chlorine dose at $7 \mathrm{ml} / \mathrm{s}$ solution flow rates from the collected samples $77.78 \%$ has found between $0.1-0.2 \mathrm{mg} / 1$ and $22.22 \%$ above $0.2 \mathrm{mg} / \mathrm{l}$. In the same way, $2 \mathrm{~kg} / 6.17 \mathrm{ml} / \mathrm{s}$ from collected samples of $55.56 \%$ has been found between $0.2-0.5$ $\mathrm{mg} / \mathrm{l}$. Although, most of the results from the analysis were within the recommended values some of the results indicate above the maximum limits and some of them were below the minimum limits (i.e. $11.11 \%$ of the samples resulted $0.65 \mathrm{mg} / \mathrm{l}$ and $33.34 \%$ results below $0.1 \mathrm{mg} / \mathrm{l})$. So that, to balance residual chlorine use $2 \mathrm{~kg}$ dose by 4.28 $\mathrm{ml} / \mathrm{s}$ flow rates $75 \%$ of the distribution systems have within the range of $0.2-0.5 \mathrm{mg} / 1$ and the rest $25 \%$ was less than $0.2 \mathrm{mg} / \mathrm{l}$. The physicochemical characteristics of water quality analysis revealed that all parameters except $\mathrm{pH}$ results were within the recommended value. But, the value of $\mathrm{pH}$ has found between $8.68-9.1$ ranges.

When, age increases throughout the networks, there was high consumption of chlorine due to this reason it may be no existing residual chlorine in pipe networks. Water age was the most factors for deteriorating water quality and reduction of chlorine in the water pipes. Using $2 \mathrm{~kg}$ chlorine dose, residual chlorine model was developed by initial concentration within three different scenarios. Scenario I and II were developed with $0.6 \mathrm{mg} / \mathrm{l}$ and $0.5 \mathrm{mg} / \mathrm{l}$ initial concentration respectively. Scenario I was near to service reservoir which was displayed above $0.5 \mathrm{mg} / \mathrm{l}$. Scenario II, all results have displayed below $0.5 \mathrm{mg} / \mathrm{l}$ but, it was not addressing all the networks within a day. Third scenario was install two injection points within 0.15 and $0.2 \mathrm{mg} / \mathrm{l}$ chlorine dose initial concentration to confirm area where cannot get minimum level of residual chlorine. In this case, all distribution networks have residual chlorine with acceptable standard limits. Therefore, the third model scenario was the best mechanism to alleviate the situation to minimize shortage of chlorine problems.

\section{REFERENCE}

Bolton, J. R. and C. A. Cotton (2011). The ultraviolet disinfection handbook, American Water Works Association. Goyal, R. V. and H. Patel (2015). "Analysis of residual chlorine in simple drinking water distribution system with intermittent water supply." Applied Water Science 5(3): 311-319.

Hu, C.-M. J., S. Aryal and L. Zhang (2010). "Nanoparticle-assisted combination therapies for effective cancer treatment." Therapeutic delivery 1(2): 323-334.

Kabir, G., S. Tesfamariam, A. Francisque and R. Sadiq (2015). "Evaluating risk of water mains failure using a Bayesian belief network model." European Journal of Operational Research 240(1): 220-234.

Males, R. M., W. M. Grayman and R. M. Clark (1988). "Modeling water quality in distribution systems." Journal of Water Resources Planning and Management 114(2): 197-209.

Mekonnen, D. K. (2015). "The effect of distribution systems on household drinking water quality in Addis Ababa, Ethiopia, and Christchurch, New Zealand."

Myre, E. and R. Shaw (2006). "The turbidity tube: simple and accurate measurement of turbidity in the field." Michigan Technological University. 
Ododo, M. M. "Physico-chemicals and Heavy Metals Analysis of Drinking Water of Aksum University, Tigrai region, Ethiopia."

Post, G., T. Atherholt and P. Cohn (2011). "Water quality and treatment: a handbook on drinking water." Health and aesthetic aspects of drinking water, 6th edn. McGraw-Hill, New York: 2.1-2.100.

Sorlini, S., D. Palazzini, J. Sieliechi and M. Ngassoum (2013). "Assessment of physical-chemical drinking water quality in the Logone Valley (Chad-Cameroon)." Sustainability 5(7): 3060-3076.

Soyupak, S., H. Kilic, I. Karadirek and H. Muhammetoglu (2011). "On the usage of artificial neural networks in chlorine control applications for water distribution networks with high quality water." Journal of Water Supply: Research and Technology-Aqua 60(1): 51-60.

Temgoua, E. (2011). "Chemical and bacteriological analysis of drinking water from alternative sources in the Dschang municipality, Cameroon." Journal of Environmental Protection 2(5): 620.

Ustad, I. (2018). "BACTERIOLOGICAL ANALYSES OF WATER USED FOR DRINKING FROM BOREHOLE OF OMERGA REGION, OSMANABAD DISTRICT IN MAHARASHTRA."

Wei, J., B. Ye, W. Wang, L. Yang, J. Tao and Z. Hang (2010). "Spatial and temporal evaluations of disinfection by-products in drinking water distribution systems in Beijing, China." Science of the Total Environment 408(20): 4600-4606.

Yee, L. F., M. P. Abdullah, S. Ata and B. Ishak (2006). "Dissolved organic matter and its impact on the chlorine demand of treated water." Malaysian Journal of Analytical Sciences 10(2): 243-250. 